\title{
FAKTOR-FAKTOR YANG MEMPENGARUHI KEPUTUSAN WISATAWAN INDIA BERKUNJUNG KE BALI
}

\author{
Yohanes Sunu Dwi Aldrianto' ${ }^{1}$, I Made Sendra², I Putu Sudana ${ }^{3}$ \\ ${ }^{1}$ Email : jojoyohan24@gmail.com \\ Program Studi Industri Perjalanan Wisata, Fakultas Pariwisata, Universitas Udayana \\ ${ }^{2}$ Email : sendramade65@gmail.com \\ Program Studi Industri Perjalanan Wisata, Fakultas Pariwisata, Universitas Udayana \\ ${ }^{3}$ Email : sudanaputu@yahoo.com \\ Program Studi Industri Perjalanan Wisata, Fakultas Pariwisata, Universitas Udayana
}

\begin{abstract}
Bali has been known for its natural beauty, the friendliness of its residents, and the diversity of its customs. Existing tourist attractions in Bali have a diversity of cultures in each region. The existence of similarities cultural between India and Bali resulted Indian tourist visits Bali increase rapidly from the previous year. The purpose of this research is to find out the factors that influence the decision of Indian tourists to visit Bali. This research was dig by using 150 respondents, the sample in this research used purposive sampling method. Data was collected through a questionnaire distributed to Indian tourists who traveled to Bali, then analyzed by using factor analysis then the data processed by the SPSS version 17.0 program. The result of this research revealed that pull factor formed by service quality factors with eigen value 6.500 , relaxation factor with eigen value 2.158 , family factor with eigen value 1.789 , nature factor with eigen value 1.342 and push factor that formed by social interaction factor with eigen value 1.116. Dominant factor that influencing the decision of Indian tourists to visit Bali is VFR factor (Visiting Friends and relatives) with eigen value of 6,500.
\end{abstract}

\begin{abstract}
Abstrak: Bali terkenal dengan keindahan alamnya, keramah tamahan penduduknya, adat istiadatnya, atraksi wisata serta mempunyai keaneka ragaman kebudayaan di masing-masing daerahnya. Adanya persamaan budaya antara India dengan Bali mengakibatkan kunjungan wisatawan India ke Bali meningkat pesat dari tahun sebelumnya. Peneliatan ini bertujuan mengetahui faktor-faktor yang mempengaruhi keputusan wisatawan India berkunjung ke Bali. Penelitian ini dilakukan dengan melalukan survey terhadap 150 responden. Jumlah sampel dalam penelitian ini dipilih dengan menggunakan metode purposive sampling. Data dikumpulkan melalui kuesioner yang disebarkan kepada wisatawan India yang melakukan kunjungan ke Bali. Analisis data menggunakan analisis faktor. Data diolah dengan menggunakan program SPSS versi 17.0. Dari hasil penelitian terungkap bahwa faktor penarik yang terbentuk, yaitu faktor kualitas pelayanan dengan eigen value sebesar 6.500, faktor relaksasi eigen value sebesar 2.158, faktor keluarga eigen value sebesar 1.789, faktor alam memiliki eigen value sebesar 1.342 , dan faktor pendorong yang terbentuk dari interaksi sosial memiliki eigen value sebesar 1.116. Faktor dominan yang mempengaruhi keputusan wisatawan India berkunjung ke Bali adalah faktor VFR (Visiting Friends and Relatives) dengan eigen value terbesar 6.500.
\end{abstract}

Keywords : factor analysis, tourist decision, indian tourist. 


\section{PENDAHULUAN}

Indonesia menetapkan Bali sebagai destinasi pariwiasata yang merupakan daerah pusat wisata yang terkenal dengan keaneka ragamannya, tempat wisatanya dan keindahan alamnya, keramah tamahan penduduknya, adat istiadatnya, atraksi wisata serta mempunyai keaneka ragaman kebudayaan masing-masing daerah yang ada di Bali. Keadaan ini membuka peluang bagi industri pariwisata, yang mengakibatkan kunjungan wisatawan mancanegara ke Bali dari tahun 2013 sampai tahun 2018 meningkat menjadi 769.802 orang. Diketahui bahwa jumlah kunjungan wisatawan ke Bali dalam kurun waktu 2013 - 2018 selalu mengalami peningkatan yang cukup signifikan padatahun 2017 dengan rata-rata peningkatan wisatawan sebesar $23,14 \%$ dan total rata-rata dari kurun waktu 5 tahun sebesar 15,07\%.

Jumlah Kunjungan Wisatawan mancanegara (wisman) berasal dari 10 negara dengan urutan terbanyak yakni wisatawan Australia, China, India kemudian Malaysia, Jepang, dan Inggris. Fenomena yang menarik terjadi pada wisatawan asal India, dari lima tahun terakhir, pada tahun 2013 sampai tahun 2014 wisatawan India belum memasuki peringkat 10 besar kunjungan wisman terbanyak ke Bali. Namun dalam kurun waktu empat tahun dimulai pada tahun 2015, jumlah wisman asal India mulai meningkat. Wisman asal India menjadi wisatawan mancanegara terbanyak ketiga yang berkunjung ke Bali setelah Tiongkok dan Australia dengan persentase sebesar $5,83 \%$ dari keseluruhan wisman yang berkunjung ke Bali pada tahun 2018.

Motivasi merupakan faktor penting bagi wisatawan di dalam pengambilan keputusan mengenai daerah tujuan wisata yang akan di kunjungi. Wisatawan akan mempersepsikan daerah tujuan wisata secara individu yang diperoleh dari pengalaman dan informasi.

Faktor budaya diprediksi menjadi salah satu faktor penarik wisatawan India untuk berwisata ke Bali. Kemiripan budaya antara India dan Bali tidak dapat terlepas dari unsur agama Hindu yang mana menjadi agama mayoritas penduduk baik di India maupun di Bali. India dan Bali sama-sama berpenduduk mayoritas Hindu namun ajaran Agama Hindu yang terdapat di kedua daerah tersebut agak berbeda, meskipun ajaran Agama Hindu yang ada di Indonesia atau khususnya Bali berasal dari India. Ajaran Agama Hindu di Bali berakulturasi dengan kebudayaan masyarakat Bali sendiri, sehingga meskipun terkesan sama namun pada kenyataannya terdapat perbedaan. Perbedaan itulah yang kemudian dapat menjadi suatu daya tarik atau keunikan yang dapat menarik minat wisatawan asal India untuk berwisata ke Bali.

Penduduk di India tercatat mencapai 1.368.737.513 jiwa dengan penetrasi pengguna internet sebesar $40,91 \%$ dari total penduduk di India. Peningkatan kunjungan wisman India ke Bali didukung oleh perkembangan teknologi digital, seperti internet memudahkan wisatawan untuk mendapatkan informasi tentang daerah tujuan wisata ditambah lagi dengan adanya beberapa penerbangan langsung dari India ke Bali. Maskapai Garuda Indonesia yang baru meresmikan rute penerbangan yaitu, Denpasar-Mumbai-Denpasar, dan Air Asia juga menawarkan penerbangan langsung dari Kolkata-Denpasar dan sebaliknya, serta beberapa rute penerbangan lainnya dari maskapai luar negeri, seperti New DelhiDenpasar, Chennai-Denpasar, dan KochiDenpasar.

Dalam hal ini kedatangan wisman asal India membuka peluang besar bagi pariwisata Bali. Untuk meningkatkan jumlah kunjungan mereka ke Bali, maka pengusaha travel agen harus mengetahui perilaku wisman asal India yang bertujuan untuk memahami dan memenuhi kebutuhan dari wisman asal India selama berwisata di Bali. Apabila mereka mendapatkan pelayanan terbaik berimplikasi terhadap kepuasan wisatawan, sehingga timbul keinginan untuk berkunjung kembali dan mempromosikan citra bagus Bali dari mulut ke mulut (the word of mouth) kepada teman-teman dan keluarga mereka.

Memahami kebutuhan wisatawan melalui perilakunya sangat penting untuk diketahui oleh para pelaksana dan pengambil kebijakan kepariwisataan di Bali. Salah satu hal paling fundamental yang harus diketahui oleh para pengambil kebijakan adalah alasan dibalik suatu pembelian atau alasan mengapa wisatawan asal India memilih untuk berwisata ke Bali dibandingkan destinasi wisata lainnya.

\section{METODE}

Penelitian ini dilakukan di daya tarik wisata Tanah Lot, Uluwatu, dan Ubud. Lokasi 
ini dipilih karena merupakan lokasi yang ramai dikunjungi oleh wisatawan India ketika berkunjung ke Bali, selain itu juga karena ikonik daya tarik wisata ini adalah kebudayaan yang yang menjadi preferensi wisatawan India terkait dengan persamaan budaya.

Variabel motivasi dibagi menjadi dua sub variabel yaitu faktor pendorong yang dikemukakan oleh Crompton (dalam Wall \& Mathieson, 2006) dan faktor penarik yang dikemukakan oleh Ryan (dalam Pitana dan Gayatri, 2005).

Faktor pendorong dikemukakan oleh Crompton (1979) yang terdiri dari kejenuhan lingkungan kerja (escape), kenyamanan (relaxation), kegembiraan (play), mempererat hubungan kekeluargaan (strenghening family bonds), gengsi atau gaya hidup (prestige), interaksi sosial (social interaction), bertemu dengan orang-orang dan suasana romantis (romance), mempelajari orang, daerah dan kebudayaan lain (educational opportunity), keinginan menemukan diri sendiri (selffulfilment), keinginan merealisasikan mimpi atau cita-cita (wish-fulfilment).

Faktor Penarik keputusan wisatawan India dalam berkunjung ke Bali yang dikemukakan oleh Ryan (1991), yaitu terdiri dari location, culture, national promotion, retail advertising, wholesale marketing, special price, service and good facilities, incentive schemes, visiting friends, visiting relatives, tourist attraction, and natural environment, man-made environment.

Teknik pengumpulan data dilakukan dengan metode observasi, kuesioner, studi kepustakaan, dan dokumentasi. Teknik pengambilan sampel menggunakan teknik purposive sampling Slovin (Sugiyono, 2011) sebanyak 100 wisatawan yang berkunjung ke daya tarik wisata di Bali. Karena lokasi penelitian terbagi tiga maka pembagian sampel di bagi sebanyak jumlah lokasi, yaitu sebanyak 33 pada masing - masing lokasi penelitian. Hal ini dilakukan untuk mempermudah dalam pengolahan data dan untuk hasil pengujian data.

Teknik analisis data yang digunakan dalam penelitian ini adalah teknik analisis deskriptif kuantitatif. Metode penelitian ini dilakukan untuk mengungkapkan faktor-faktor yang mempengaruhi keputusan wisatawan India dalam berkunjung ke Bali yang dilakukan lewat penyebaran kuesioner yang disebarkan kepada wisatawan yang sedang melakukan kunjungan di Bali.
Pengolahan data menggunakan analisis faktor yang dibagi menjadi dua, yaitu Uji Validitas (keabsahan) dan Uji Reliabilitas (Uji Instrument). Uji Validitas dilakukan dengan mengukur korelasi antar variabel atau item dengan skor total variabel. sedangkan uji reliabilitas merupakan indeks yang menunjukan sejauh mana alat ukur dapat dipercaya atau dapat diandalkan. Pengujian validitas dan reliabilitas kuesioner dalam penelitian ini dilakukan dengan cara 30 kuesioner kepada 30 responden secara acak, setelah data di tabulasikan maka pengujian dilakukan dengan menggunakan SPSS.

Analisis faktor digunakan untuk menjawab tujuan penelitian yakni agar dapat mengetahui faktor yang mempengaruhi keputusan wisatawan India dalam berkunjung ke Bali. Data dalam penelitian ini diolah menggunakan program SPSS for windows. Jenis analisis faktor yang digunakan dalam penelitian ini adalah analisis ekploratoris karena jumlah faktor (konstruk) serta variabel mana saja yang terkait dengan faktor tertentu secara apriori belum ada atau tidak diketahui. Menurut Santoso (2010) tahapan dalam analisis faktor terdiri dari menentukan indikator-indikator,uji kelayakan variable, uji MSA, menentukan jumlah factor, rotasi factor, Interpretasi faktor yang dimaksud disini adalah pemberian nama atas faktor yang terbentuk yang dianggap bisa mewakili indikator-indikator anggota faktor tersebut.

\section{HASIL DAN PEMBAHASAN Gambaran Umum}

Provinsi Bali merupakan provinsi di Indonesia yang menjadikan sektor pariwisata sebagai sektor unggulan (leading sector), tercatat pada tahun 2012 lebih dari 65\% perekonomian di Bali dipengaruhi oleh industri pariwisata. Penelitian ini dilakukan di beberapa destinasi wisata di Bali, yaitu Tanah Lot, destinasi wisata Uluwatu, dan Ubud. Tanah Lot adalah sebuah objek wisata di Bali, terletak di atas batu karang laut besar menghadap ke samudra Hindia, dan menjadi tempat ibadah (Pura) bagi umat Hindu. Tanah Lot berlokasi di Desa Beraban, Kecamatan Kediri, Kabupaten Tabanan, di pesisir selatan pulau Bali kurang lebih 25 kilometer dari Kota Denpasar.

Destinasi wisata Uluwatu terletak di Desa Pecatu, Kecamatan Kuta, Kabupaten 
Badung, Bali, sekitar $30 \mathrm{~km}$ ke arah selatan dari kota Denpasar. Destinasi wisata Uluwatu yang juga disebut Pura Kahyangan yang dianggap sebagai pilar spiritual di Bali. Destinasi wisata Uluwatu menempati lahan di sebuah tebing yang tinggi yang menjorok ke Samudera Indonesia dengan ketinggian 97 meter dari permukaan laut. Di depan pura terdapat hutan kecil yang disebut Alas (Hutan) Kekeran, berfungsi sebagai penyangga kesucian Pura.

Destinasi wisata Ubud salah satu tujuan liburan populer di Bali. Kawasan pariwisata Ubud identik dengan seni, budaya serta keindahan alam pedesaan. Untuk budaya, di Ubud banyak terdapat objek wisata pura Hindu serta keindahan istana kerajaan. Keindahan alam juga menjadi keunggulan pariwisata Ubud, wisatawan dapat melihat lereng bukit hijau, sawah berundak, serta sungai yang masih alami. Kawasan pariwisata Ubud masuk dalam pemerintahan Kabupaten Gianyar. Kabupaten Gianyar sebagai tempat wisata terkenal memiliki banyak seniman berbakat dan dapat dikatakan merupakan pusat budaya dan seni di Bali. Khususnya untuk seni lukis, seni ukir, seni patung, seni tari dan seni musik traditional Bali. Kota Ubud, terletak di bagian tengah pulau Bali

\section{Karakteristik Wisatawan India Yang Berkunjung ke Bali}

Berdasarkan hasil analisis perhitungan di atas usia wisatawan India yang paling banyak dalam berkunjung ke Bali berusia 25-30 tahun sebesar 52\%, selanjutnya umur 31-35 tahun sebesar 15\%, berikutnya umur 18-24 tahun sebesar 14\%, setelah itu umur 36-40 tahun sebesar 10\% dan yang terakhir umur 41-47 tahun keatas sebesar 9\%. Hal ini dikarenakan wisatawan India yang berkunjung ke Bali dominasi oleh usia produktif dan sedang dalam masa mencari sesuatu seperti pengalaman, maka usia produktif yang menjadi paling banyak dalam berwisata terutama melakukan perjalanan wisata ke Bali.

Wisatawan India yang berkunjung ke Bali paling banyak sebagai pegawai swasta sebesar $51 \%$, selanjutnya pengusaha sebesar $19 \%$, setelah itu pegawai pemerintahan sebesar $16 \%$, dan yang terakhir sebagai pelajar sebesar $14 \%$. Hal ini dikarenakan wisatawan yang berkunjung ke Bali sedang dalam musim liburan, maka pegawai swasta yang paling banyak berkunjung ke Bali.

Jenis kelamin wisatawan India yang berkunjung ke Bali paling banyak adalah perempuan sebesar 55\% dan laki-laki paling sedikit sebesar 45\%. Hal ini dikarenakan wisatawan India yang berkunjung ke Bali banyak dengan pasangan mereka, berkelompok dan bersama keluarga, dan bisa dikatakan bahwa wisatawan India yang berkunjung ke Bali tidak ada yang melakukan perjalanan sendirian.

Status perkawinan wisatawan India yang berkunjung ke Bali di dominasi oleh menikah, yaitu sebesar 59\% untuk status mereka sudah menikah dan $41 \%$ untuk status belum menikah (single). Hal ini dikarenakan wisatawan India yang berkunjung ke Bali banyak yang berpasangan-pasangan, dan berdasarkan analisa penelitian wisatawan India yang berpergian ke Bali banyak untuk mempererat hubungan mereka dengan pasangan ataupun keluarga mereka.

Berdasarkan pendidikan terakhir wisatawan India yang berkunjung ke Bali di dominasi oleh pendidikan sarjana sederajat yaitu sebesar 46\%, selanjutnya sekolah menengah atas sederajat sebesar $31 \%$, berikutnya master sederajat sebesar $19 \%$ dan yang terakahir doctoral sebesar $4 \%$. Hal ini dikarenakan wisatawan banyak yang berumur produktif dan sudah selesai dalam masa belajar/sekolah, maka banyak wisatawan India yang berkunjung ke Bali memiliki pendidikan terakhir sarjana sederajat, karena sarjana sederajat merupakan pendidikan terakhir yang standar untuk bisa mendapatkan perkerjaan ditambah banyaknya pekerjaan wisatawan yang menjadi pegawai swasta.

Wisatawan India yang berkunjung ke Bali berdasarkan pengorganisasian perjalanan mereka didominasi oleh pengorganisasian sendiri, yaitu sebesar $62 \%$, dan yang paling rendah adalah lainnya sebesar 5\%. Hal ini disebabkan wisatawan India yang berkunjung ke Bali adalah untuk berekreasi dan bersantai serta memperat hubugan dengan keluarga. Wisatawan perlu layanan jasa lain sebagai fasilitator, seperti transportasi. Berdasarkan hasil observasi wisatawan melakukan semuanya berdasarkan apa yang mereka ingin dan butuhkan.

Lama tinggal wisatawan India yang berkunjung ke Bali paling banyak sebesar $41 \%$ ( $4-7$ hari) dan paling sedikit $8 \%$ ( $<3$ hari), hal ini dikarenakan wisatawan India yang berwisata ke Bali lebih menikmati berlibur 
sepekan di Bali dan segera balik ke negara asalnya.

\section{Analisis Skala Kesesuain Tanggapan Wisatawan}

Berdasarkan hasil penelitian melalui kuisioner yang disebarkan secara menyeluruh maka dapat diketahui gambaran skala keputusan wisatawan India yang berkunjung ke Bali. Uraian mengenai tanggapan wisatawan di bagi menjadi dua variabel, yaitu faktor pendorong dan faktor penarik. Faktor pendorong terdiri dari 10 indikator dan faktor penarik terdiri dari 9 indikator. Masing - masing indikator dari setiap variabel di berikan skala interval dari $1-5$, yang memiliki arti 1 sama dengan sangat tidak setuju dan 5 sama dengan sangat setuju.

Tabel 1. Perhitungan Skala Sikap (Skala Likert)

\begin{tabular}{|c|c|c|c|c|}
\hline No & Indikator & $\begin{array}{c}\text { Rata- } \\
\text { rata }\end{array}$ & Ket & Kode \\
\hline 1 & $\begin{array}{l}\text { Melepaskan diri dari } \\
\text { kejenuhan }\end{array}$ & 4.17 & Setuju & $\mathrm{X} 1.1$ \\
\hline 2 & Relaksasi & 4.27 & $\begin{array}{l}\text { Sangat } \\
\text { Setuju }\end{array}$ & $\mathrm{X} 1.2$ \\
\hline 3 & Hiburan/Bermain & 4.36 & $\begin{array}{l}\text { Sangat } \\
\text { Setuju }\end{array}$ & $\mathrm{X} 1.3$ \\
\hline 4 & $\begin{array}{l}\text { Memperkuat ikatan } \\
\text { keluarga }\end{array}$ & 4.22 & $\begin{array}{l}\text { Sangat } \\
\text { Setuju }\end{array}$ & $\mathrm{X} 1.4$ \\
\hline 5 & Gengsi & 4.29 & $\begin{array}{l}\text { Sangat } \\
\text { Setuju }\end{array}$ & $\mathrm{X} 1.5$ \\
\hline 6 & Interaksi Sosial & 4.01 & Setuju & $\mathrm{X} 1.6$ \\
\hline 7 & Suasana Romantis & 4.37 & $\begin{array}{l}\text { Sangat } \\
\text { Setuju }\end{array}$ & $\mathrm{X} 1.7$ \\
\hline 8 & Peluang Pendidikan & 4.15 & Setuju & $\mathrm{X} 1.8$ \\
\hline 9 & Pemenuhan diri & 4.42 & $\begin{array}{l}\text { Sangat } \\
\text { Setuju }\end{array}$ & X1.9 \\
\hline 10 & Skema Insentif & 4.12 & Setuju & $\mathrm{X} 1.10$ \\
\hline \multicolumn{2}{|c|}{$\begin{array}{c}\text { Rata-rata Total Faktor } \\
\text { Pendorong }\end{array}$} & 4.24 & \multicolumn{2}{|c|}{ Sangat Setuju } \\
\hline 11 & Lokasi & 4.35 & $\begin{array}{l}\text { Sangat } \\
\text { Setuju }\end{array}$ & $\mathrm{X} 2.1$ \\
\hline 12 & Budaya & 4.19 & Setuju & $\mathrm{X} 2.2$ \\
\hline 13 & Promosi Nasional & 4.14 & Setuju & $\mathrm{X} 2.3$ \\
\hline 14 & Harga Spesial & 4.07 & Setuju & $\mathrm{X} 2.4$ \\
\hline 15 & $\begin{array}{c}\text { Pelayanan dan Fasilitas } \\
\text { Bagus } \\
\end{array}$ & 4.17 & Setuju & $\mathrm{X} 2.5$ \\
\hline 16 & $\begin{array}{c}\text { Mengunjungi Teman } \\
\text { dan Kerabat }\end{array}$ & 3.92 & Setuju & $\mathrm{X} 2.6$ \\
\hline 17 & Atraksi Wisata & 3.94 & Setuju & $\mathrm{X} 2.7$ \\
\hline 18 & Lingkungan Alami & 4.29 & $\begin{array}{l}\text { Sangat } \\
\text { Setuju }\end{array}$ & X2.8 \\
\hline 19 & $\begin{array}{c}\text { Lingkungan buatan } \\
\text { Manusia }\end{array}$ & 4.14 & Setuju & $\mathrm{X} 2.9$ \\
\hline \multicolumn{2}{|c|}{$\begin{array}{c}\text { Rata-rata Total Faktor } \\
\text { Penarik }\end{array}$} & 4.13 & \multicolumn{2}{|c|}{ Setuju } \\
\hline
\end{tabular}

Sumber: Hasil Penelitian, 2019.

Dari hasil keputusan wisatawan India yang berkunjung ke Bali menurut skala interval keputusan. Keputusan wisatawan menurut jawaban dari hasil kuesioner wisatawan SelfFulfilment (X2.6) adalah keputusan tertinggi wisatawan untuk berkunjung ke Bali dengan skor 4.42 dalam kategori sangat setuju. Hal ini dikarenakan wisatawan India berkunjung ke Bali lebih termotivasi oleh pemenuhan kebutuhan pribadi yang mereka inginkan. Sedangkan keputusan terendah wiatawan adalah Visiting Friends and relatives (VFR) (X2.6) dengan skor 3.92 dalam kategori setuju. Hal ini dikarenakan wisatawan merasa memiliki sedikit kenalan yang akan dikunjungi di Bali yang memutuskan mereka untuk berwisata dengan alasan mengunjungi kerabat.

Analisis Pengujian Instrument FaktorFaktor Yang Mempengaruhi Keputusan Wisatawan Dalam Berkunjung Ke Bali

Uji Validitas merupakan pengujian yang digunakan untuk menguji valid tidaknya suatu instrument yang digunakan dalam penelitian. Instrumen tersebut dikatakan valid apabila koefisiennya melebihi $0,361(\mathrm{df}=\mathrm{n}-\mathrm{k}$, dengan Sig 5\%). Uji validitas dapat dilakukan dengan melihat korelasi antara skor masing-masing item dalam kuesioner dengan total skor yang ingin diukur.

Bahwa terdapat 19 variabel yang diuji validitasnya dan sesuai dengan persyaratannya variabel yang memiliki nilai koefisien melebihi dari dari 0,361 (df n-2) Dalam penelitian seluruh indikator yang duji validitas dapat dikatakan valid, dari 19 variabel yang diuji tersebut semua variabel memiliki nilai lebih dari 0.361, karena semua variabel tersebut valid, maka akan digunakan dalam pengujian selanjutnya yaitu uji reliabilitas dan.analisis data.

Pengujian reliabilitas ini digunakan untuk melakukan pengujian terhadap hasil dari jawaban kuesioner yang telah dilakukan. Fungsi dari uji reliabilitas ini dilakukan untuk memperoleh hasil penelitian yang reliabel. Dari hasil uji reliabilitas terhadap 30 responden yang dijadikan sampel didapatkan hasil bahwa nilai Cronbach's Alpha adalah sebesar 0,948, nilai ini dikatakan tersebut telah memenuhi syarat atau reliable, karena nilainya lebih dari 0,6. Hal ini menunjukkan bahwa kuesioner yang telah diuji dapat memberikan hasil yang konsisten bila nantinya dilakukan pengujian atau pengukuran kembali.

Hasil Faktor yang Mempengaruhi 


\section{Keputusan Wisatawan India dalam Berkunjung ke Bali}

Untuk mengetahui suatu variabel dalam kuesioner memiliki pengaruh atau tidak berpengaruh terhadap keputusan pembelian maka harus dilakukan analisis faktor untuk menemukan sejumlah variabel yang benar-benar berpengaruh.

Melalui analisis faktor, dapat diketahui factor-faktor yang mempengaruhi keputusan wisatawan India dalam berkunjung ke Bali yang dapat diidentifikasi dari 19 variabel penentu keputusan. Responden dari penelitian berjumlah 100 orang sampel yang diambil dari wisatawan India yang ditemui dan berkunjung di daya tarik wisata yang ada di Bali sesuai dengan lokasi penelitian.

Matriks korelasi dapat diidentifikasikan variabel-variabel mana saja yang terkait satu sama lain dan saling berhubungan dari ke-19 variabel yang dianalisis. Untuk menguji hal tersebut, maka dilakukan langkah - langkah yang terdiri dari uji Bartlett's, uji KMO, dan uji MSA. Dapat diketahui bahwa dari ke 19 variabel yang ada, semua variabel yang memiliki nilai lebih dari 0,5, dengan hasil ini maka semua variabel digunakan pada analisis selanjutnya karena memenuhi persyaratan nilai standar dari MSA > 0,5, sehingga dapat dikatakan memenuhi syarat nilai standar dari MSA dan dapat digunakan pada analisis selanjutnya.

Berdasarkan pada besarnya eigenvalue setiap faktor yang muncul. Semakin besar eigenvalue setiap faktor, semakin representatif faktor tersebut untuk mewakili sekelompok variabel. Faktor-faktor inti yang dipilih adalah faktor yang mempunyai eigenvalue $\geq 1$, maka dapat dijelaskan bahwa dalam tahap ini terbentuk lima faktor dari 19 variabel yang mempengaruhi keputusan wisatawan India dalam berkunjung ke Bali. Kelima faktor tersebut memiliki eigenvalue> 1, yaitu 6.500, $2.158,1.789,1.342$ dan 1.116 dengan nilai Cumulative eigenvalue sebesar 67,919\%. Berdasarkan pada nilai percent of variance, diketahui bahwa faktor yang menyumbangkan bagian variasi terbesar dari keseluruhan yang dianalisa adalah faktor ke-1 yaitu sebesar $34,211 \%$. Dengan demikian dapat diketahui bahwa faktor yang terbentuk menjelaskan $67,919 \%$ total varian variabel yang mempengaruhi keputusan wisatawan India dalam berkunjung ke Bali.

Hasil analisis rotasi maka dapat dijelaskan bahwa dari ke 19 variabel yang telah dirotasi, terdapat 16 variabel yang memenuhi syarat atau kriteria dan terdapat 3 variabel yang tidak memenuhi kriteria dikarenakan loading factor yang tidak mencapai 0,5. Variabel yang dimaksud adalah Bermain/hiburan (Play) (X1.3), Gengsi (Prestige) (X1.5) dan Pemenuhan Diri (Self-Fulfilment) (X1.9).

Dengan menggunakan metode Principal Componen Analisis (PCA), maka variabel yang tersisa tersebar dalam lima faktor yang merupakan faktor-faktor yang mempengaruhi keputusan wisatawan India dalam berkunjung ke Bali. Adapun komponen variabel yang masuk ke dalam faktor yang pertama terdiri dari Peluang Pendidikan (Educational Opportunity) (X1.8), Promosi Nasional (National Promotion) (X2.3), Harga Spesial (Special Price) (X2.4), Mengunjungi Teman dan Kerabat (Visiting Friends and relatives) (VFR) (X2.6), Atraksi Wisata (Tourist Attraction) (X2.7), dan Lingkungan Buatan Manusia (Man-Made Environment) (X2.9). Variabel yang lainnya masuk ke faktor yang kedua terdiri Melepaskan Diri dari kejenuhan (Escape) (X1.1), Relasasi (Relaxation) (X1.2), dan Suasana Romantis (Romance) (X1.7). Variabel selanjutnya masuk ke dalam faktor yang ketiga, yaitu Memperkuat Ikatan Keluarga (Strengthening Family Bonds) (X1.4), Insentif Skema (Incentive Schemes) (X1.10), dan Lokasi (Location) (X2.1). Variabel selanjutnya masuk ke dalam faktor yang keempat yaitu Pelayanan dan Fasilitas Bagus (Service And Good Facilities) (X2.5), dan Lingkungan Alami (Natural Environment) (X2.8). Variabel terakhir masuk ke dalam faktor yang kelima yaitu Interaksi Sosial (Social Interaction) (X1.6), dan Budaya (Culture) (X2.2).

Terlihat pada faktor pertama memiliki nilai eigenvalue sebesar 6.500 dengan total variance $34,211 \%$, faktor kedua memiliki nilai eigenvalue sebesar 2.158 dengan total variance $11,356 \%$, faktor ketiga memiliki nilai eigenvalue sebesar 1.789 dengan total variance 9, 414\%, faktor keempat memiliki nilai eigenvalue sebesar 1.342 dengan total variance $7,063 \%$, faktor kelima memiliki nilai eigenvalue sebesar 1.116 dengan total variance $5,875 \%$. Faktor ini merupakan faktor-faktor yang mempengaruhi keputusan wisatawan India dalam berkunjung ke Bali.

Pada tahapan ini faktor yang merupakan gabungan dari suatu variabel harus diberi 
nama. Pemberian nama harus mengacu pada variabel-variabel yang membentuk faktor yang bersangkutan atau berdasarkan pada variabel yang mempunyai loading factor tertinggi dibandingkan variabel lain yang berada dalam satu faktor tersebut. Ditemukan lima faktor terdiri atas 16 variabel yang memiliki pengelompokan baru. Faktor-faktor baru yang telah terbentuk diberi nama sesuai dengan variabel yang telah dikelompokan. Hal ini dapat dapat diuraikan sebagai berikut:

1. Faktor 1

Faktor pertama diberi nama faktor eksternal yang memiliki nilai eigen value sebesar 6.500. Adapun faktor eksternal terdiri dari atas Mengunjungi teman dan kerabat (visiting friends and relatives (VFR), harga spesial (special price), peluang pendidikan (educational opportunity), promosi nasional (national promotion), lingkungan buatan manusia (man-made environment), dan atraksi wisata (tourist attraction).

2. Faktor 2

Faktor kedua diberi nama faktor relaksasi yang memiliki nilai eigenvalue sebesar 2.158. Adapun faktor relaksasi terdiri atas variabel relaxation, suasana romantis (romance), dan melepaskan diri dari kejenuhan (escape).

3. Faktor 3

Faktor yang ketiga diberi nama faktor hadiah untuk keluarga yang memiliki nilai eigenvalue sebesar 1.789. Adapun faktor hadiah untuk keluarga terdiri atas variabel memperkuat ikatan keluarga (strenghening family bonds), lokasi (location), dan skema insentif (incentive schemes).

4. Faktor 4

Faktor yang keempat diberi nama faktor ketersediaan sarana yang memiliki nilai eigenvalue sebesar 1.342. Adapun faktor ketersediaan terdiri atas variabel lingkungan alami (natural environment), dan pelayanan dan fasilitas bagus (service and good facilities).

5. Faktor 5

Faktor yang kelima diberi nama faktor sosial budaya yang memiliki nilai eigenvalue sebesar 1.116. Adapun faktor sosial budaya terdiri atas variabel interaksi sosial (social interaction), dan budaya (culture).

\section{Analisis Faktor-faktor Yang Mempengaruhi Keputusan Wisatawan India dalam Berkunjung ke Bali}

Adapun hasil yang diperoleh membentuk konsep baru, yang mana menunjukan bahwa dari 2 faktor awal dengan total 19 indikator di atas, maka faktor - faktor yang mempengaruhi keputusan wisatawan India dalam berkunjung ke Bali dan menghasilkan 5 faktor terbentuk dengan 16 variabel didalamnya. Hal tersebut dapat diuraikan sebagai berikut :

1. Faktor yang pertama yaitu faktor eksternal, terdiri dari: (1) visiting friends and relatives (vfr), (2) special price, (3) educational opportunity, (4) national promotion, (5) man-made environment dan (6) tourist attraction. Faktor eksternal yang diberi nama dalam penelitian ini berkaitan dengan konsep yang diterapkan oleh Ryan (1991) bahwa lingkungan eksternal adalah hal yang dapat menarik seseorang untuk berkunjung. Faktor eksternal merupakan faktor yang menarik wisatawan untuk berkunjung ke suatu tempat.

2. Faktor yang kedua yaitu faktor relaksasi, terdiri dari: (1) relaxation, (2) romance, dan (3) escape. Faktor relaksasi diambil dari konsep Crompton (1979) dimana wisatawan akan terdorong untuk melakukan kunjungan ke suatu tempat dikarenakan adanya keinginan yang kuat untuk melakukan relaksasi di daerah tujuan wisata.

3. Faktor yang ketiga yaitu faktor hadiah untuk keluarga, terdiri dari: strenghening family bonds, (2) location, dan (3) incentive schemes. Faktor hadiah untuk keluarga merupakan faktor yang juga dijelaskan dalam konsepnya Crompton (1979). Dimana keluarga akan mendorong seseorang (wisatawan) untuk melakukan perjalanan wisata dalam hal memperat hubungan keluarga.

4. Faktor yang keempat yaitu faktor ketersediaan sarana, terdiri dari: (1) natural environment, dan (2) service and good facilities. Faktor alam merupakan faktor yang dijelaskan dalam konsepnya Ryan (1991). Ketersediaan sarana adalah faktor yang menarik wisatawan untuk melakukan kunjungan ke suatu daerah tujuan wisata dengan adanya lingkungan yang alami dan pelayanan yang baik serta fasilitas yang memadai mampu membuat wisatawan tertarik untuk berkunjung ke Bali.

5. Faktor yang kelima yaitu faktor sosial budaya, terdiri dari: (1) social interaction, dan (2) culture. Faktor sosial budaya 
merupakan faktor yang dijelaskan dalam konsepnya Crompyon (1979). Faktor sosial budaya terdapat dalam faktor yang mendorong seseorang untuk melakukan perjalanan wisata ke suatu daerah tujuan wisata.

\section{Analisis Faktor Dominan Yang Mempengaruhi Keputusan Wisatawan India dalam Berkunjung ke Bali}

Adapun faktor yang paling dominan yang mempengaruhi keputusan wisatawan India dalam berkunjung ke Bali dapat dilihat melalui nilai eigenvalue dalam analisis faktor yaitu sebesar 6.500. Berdasarkan hasil penelitian maka yang menjadi faktor paling dominan yaitu faktor eksternal, faktor ini terdiri dari enam indikator pembentuk yaitu: (1) visiting friends and relatives (VFR), (2) special price, (3) educational opportunity, (4) national promotion, (5) man-made environment dan (6) tourist attraction.

Faktor eksternal memiliki 6 variabel pembentuk dengan nilai paling tinggi adalah variabel Visiting Friends and relatives (VFR) (X2.6) dengan nilai MSA atau Loading Factor sebesar 0.865 dimana menurut Hair (1998) nilai Loading Factor yang melebih 0.5 adalah nilai yang signifikan. Hasil observasi mengenai Visiting Friends and relatives (VFR) (X2.6) yang didapatkan setelah analisis faktor berkaitan dengan banyaknya wisatawan India yang berkunjung beberapa tahun belakang Hal tersebut juga berhubungan dengan persamaan budaya yang dimiliki oleh Bali sebagai pulau seribu Pura dan menjadi daerah yang mayoritas memiliki persamaan kepercayaan dengan negara asal wisatawan India.

\section{SIMPULAN DAN SARAN Simpulan}

Adapun faktor-faktor yang mempengaruhi keputusan wisatawan India berkunjung ke Bali, faktor yang pertama ialah faktor eksternal yang mencangkup mengunjungi teman dan kerabat, adanya harga spesial, peluang pendidikan, promosi nasional, wisata buatan dan atraksi wisata. Faktor yang kedua, yaitu faktor relaksasi, terdiri dari suasana romantis, relaksasi, dan melepaskan diri dari kejenuhan. Faktor yang ketiga yaitu faktor keluarga, memperkuat ikatan keluarga, lokasi, dan insentive schemes. Faktor yang keempat yaitu faktor alam, adanya lingkungan alami, dan pelayan fasilitas yang bagus. Faktor yang kelima faktor sosial, adanya interaksi sosial, dan budaya.

Faktor yang paling dominan mempengaruhi keputusan wisatawan India dalam berkunjung ke Bali adalah faktor eksternal (lingkungan luar), yang terdiri dari mengunjungi teman dan kerabat, adanya harga spesial, peluang pendidikan, promosi nasional, wisata buatan dan atraksi wisata, merupakan salah satu faktor yang menarik wisatawan untuk berkunjung ke suatu tempat. Maka Faktor eksternal tersebutlah yang paling dominan mempengaruhi keputusan wisatawan India dalam berkunjung ke Bali.

\section{Saran}

Sebagian besar wisatawan India ke Bali menggunakan jasa biro perjalanan, sehingga penelitian ini merekomendasikan kepada biro jasa perjalan wisata diharapkan lebih memperhatikan pribadi konsumen terhadap perjalan wisata yang di tawarkan, dan memperhatikan faktor - faktor yang mempengaruhi keputusan konsumen berkunjung ke Bali. Mengetahui hal tersebut pelaku bisnis wisata di Bali yang menjadikan wisatawan India sebagai market utama dan mengetahui trend yang sedang dan juga produk wisata yang dibutuhkan disukai oleh wisatawan India, sehingga dapat menarik minat wisatawan India untuk berkunjung ke Bali.

Faktor sosial budaya merupakan faktor paling lemah, jadi dalam hal ini peneliti selanjutnya diharapkan lebih mampu mengukur faktor apa yang lebih mampu menjelaskan wisatawan India untuk berkunjung ke Bali. Dalam penelitian ini peneliti berhipotesa bahwa wisatawan India berkunjung ke Bali karena persamaan budaya, namun hasil dari penelitian mendapatkan bahwa budaya adalah faktor yang paling lemah dan harus dikembangkan terkait minat wisatawan India berkunjung ke Bali. 
Jurnal IPTA

Vol. 7 No. 2, 2019

p-ISSN : 2338-8633

e-ISSN : 2548-7930

\section{Kepustakaan}

Crompton, J. L. 1979. Motivations for Pleasure Vacations. Annals of Tourism Research. Vol. 6, No.4, Page. 408-424.

Ryan, K. 1986. The New Moral Education. Moral Issues: http://www.hiho.ne.jp.taku77 .pukul 19.00 WIB.

Sugiyono. 2011. Metode Penelitian Kuantitatif, Kualitatif dan R\&D. Bandung: Afabeta.

Santoso, Singgih.2010. Statistik Parametrik, Konsep dan Aplikasi dengan SPSS. Cetakan Pertama, PT Elex Media Komputindo, Jakarta, PT Gramedia, Jakarta. 